\title{
Huelgas de los peones del campo en las haciendas de Tlaxcala
}

\author{
Mario Ramírez Rancaño
}

La literatura sobre los movimientos campesinos a finales de la dictadura porfirista, cuando menos para el estado de Tlaxcala, no es prolija. Aquellos que se consideran trabajos de investigación clásicos sobre los movimientos campesinos, como lo son el de Jean Meyer, Leticia Reina o el de Gastón García Cantú, ${ }^{\mathfrak{1}}$ no incluyen a Tlaxcala. Por supuesto ello no representa una total ausencia. $Y$ es que no se puede concebir que Tlaxcala haya sido durante la dictadura porfirista una suerte de desierto lunar en el cual los brotes de descontento y de rebelion campesina estuvieron ausentes. Basta reflexionar sobre el hecho de que la entidad estaba tapizada de haciendas y ranchos desde siglos atrás, que la expansión de varias de ellas se consuma entre otros expendientes, vía el arrebatamiento de tierras de los pueblos y comunidades aledañas.

El archivo de la Comisión Nacional Agraria reporta infinidad de protestas de los campesinos a causa de los atropellos de los hacendados, cuya sistematización constituye una tarea aún por realizar. Lo que sí se conoce con cierto detalle son las rebeliones campesinas que se manifiestan en forma reiterada a causa de la decisión de Próspero Cahuantzi de eternizarse en la gubernatura. Desde el año de 1885 , en que se entroniza en el poder, se mantiene ahí y sólo la guerra civil de 1910 lo derriba de su pedestal. Tan singular decisión provoca posturas reacias entre los campesinos, quienes no vacilan en hacerle patente su descontento. Además de ello, existieron movimientos campesinos activados por la decisión del gobernador de aumentar los impuestos a la propiedad rural. Se tienen noticias de que para aplacar tales movimientos, el gobernador utilizaba la fuerza pública e incluso a los guardias rurales. En él era común implantar medidas tales como el encarcelamiento, la aplicación de la ley fuga e incluso mandarlos a colgar.

En términos generales, la llamada población campesina de Tlaxcala se divide en cuatro grupos. Aquella que ante la expansión del sistema de haciendas quedó atrapada dentro de sus confines. Se trata de una parte importante de la población rural que, al perder su tierra, no le queda más remedio que vender su fuerza de trabajo mediante la modalidad calificada como servil o acasillada. Existe además la población campesina habitante de los pueblos libres, que ante la carencia de tierras no tiene otra alternativa más que sumarse a las huestes acasilladas. Habría que considerar incluso a la población campesina que, sin perder su libertad, de todas formas se ve obligada a complementar su sustento vía el trabajo estacional en las haciendas. Su denominación clásica es la de semaneros. Y habría aún una cuarta modalidad. Se trata de la población que, teniendo como base de su sustento la pequeña propiedad o la propiedad comunal, permaneció al margen del sistema de haciendas.

Debemos remarcar que en particular los trabajadores acasillados

1 Jean Meyer, Problemas campesinos y revueltas agrarias (1821-1910), México, SepSetentas, 1973; Leticia Reina, Las rebeliones campesinas en México (1819-1906), México, Siglo XXI, 1980; Gastón García Cantú, El socialismo en México, México, ERA, 1976. 
constituían una parte importante de la población campesina, que estaban al servicio exclusivo de las haciendas y al cabo de los años se convirtieron en esclavos por deudas. Sólo recibían salario en teoría, ya que en la práctica se les pagaba con los llamados vales, canjeables exclusivamente en las tiendas de raya. Esta situación incluso fue aceptada por el sistema legal de Tlaxcala. El gobernador de la entidad, Mariano J. Grajales, de marcada tendencia esclavista, en el año de 1882 promulgó una fatídica ley en detrimento de los intereses y de la suerte de los trabajadores acasillados, ya que los convertía en esclavos. Por supuesto, el citado gobernador tramó esta ley ${ }^{2}$ en estrecha colaboración con los hacendados y el congreso local.

Debido a la escasez de trabajos de investigación, no se tienen noticias de que durante la dictadura porfirista, los trabajadores acasillados o los semaneros hayan mostrado abiertamente su descontento. Un movimiento de indudable significación, y que aquí interesa analizar, adquiere expresión justa con el ascenso de Francisco I. Madero al poder. Se trata de aquél encabezado por trabajadores semaneros y acasillados, estimulado en gran parte por los nuevos aires renovadores que se respiran en todo el país; por los grupos locales maderistas quienes, en su afán de consolidarse, urden la trama de retomar como banderas las viejas aspiraciones del campesinado de la entidad. Como era de esperarse, la lucha adquiere un tono frontal debido al acentuado predominio de la oligarquía agraria. De hecho, concientizar y movilizar a los trabajadores acasillados y a los semaneros era considerado un síntoma de sedición que atentaba en contra de los marcos del orden vigente.

\section{El Partido Antirreeleccionista de Tlaxcala}

Mucho se ha escrito sobre la descomposición política y social del régimen porfirista, de la aventura emprendida por Francisco I. Madero, orientada a "cambiar" el viejo orden de cosas, del estallido de la guerra civil y del traspaso del poder a manos de nuevos grupos políticos. Además de ello, se ha remarcado que, ante todo, el maderismo significaba un movimiento de índole política, que la meta fundamental de la revolución se expresaba en el cambio de dirigentes sin que ello implicara mayores pretensiones de transformación económica y social. Pero lo que dentro de este contexto no se ha analizado en forma suficiente es el hecho de que existieron maderistas de cuño local o regional, quienes no comulgaban con esta concepción. El Partido Nacional Antirreeleccionista fue fundado por Francisco I. Madero en 1909. ${ }^{3} \mathrm{Al}$ poco tiempo brotaron numerosos partidos políticos regionales. Entre ellos el Partido Antirreeleccionista de Tlaxcala, que no tardó en mostrar signos progresistas buscando una base de acción sólida y apoyo popular. Por supuesto que ello implicaba tomar conciencia de la grave situación imperante entre obreros y campesinos, asumir frente a ellos un compromiso militante. Pero además sus dirigentes sabían que las repercusiones podrían serles fatales a causa de que, tarde o temprano, debían enfrentarse a la oligarquía agraria.

Desde el principio, la influencia del PAT tiene enorme trascenden-

2 "J. Mariano Grajales, Gobernador Constitucional del Estado Libre y Soberano de. Tlaxcala, a sus habitantes, sabed:", en El Estado de Tlaxcala, órgano oficial del gobierno,. Tlaxcala, 9 de diciembre de 1882, p. 1-2.

3 Vicente Fuentes Díaz, Los partidos polfticos en México, México, Altiplano, 1969, p. 163. 
cia. Se orienta a organizar a los campesinos acasillados en las haciendas, cuestión que les da cierta presencia y arraigo. Pero su verdadero realce se advirtió a mediados de 1911, cuando se planteó la necesidad de elegir al nuevo gobernador. Para ese entonces el PAT ya tenía la suficiente fuerza política como para participar en las elecciones con un candidato propio. En su favor jugaba el hecho de que ya había penetrado entre las clases populares. Atraérselos ahora en plena coyuntura electoral no le era una empresa difícil. Los dirigentes del PAT, entre quienes destacan su presidente Pedro $M$. Morales y uno de sus secretarios, Porfirio del Castillo, reforzaron la política de alianza con los peones acasillados y semaneros. Esta cuestión significaba simple y llanamente meterse en los dominios de los hacendados. La adopción de banderas tales como la petición de aumento de salarios y reducción de las jornadas de trabajo, les rindieron los frutos esperados. Por otra parte, se hizo saber a los campesinos que su lucha era a todas luces legítima y que podría llegar incluso a la huelga. Esta labor de agitación, hasta cierto punto nueva en el campo tlaxcalteca, no tardó en cristalizar en una serie de rebeliones, huelgas y protestas. Porfirio del Castillo, uno de los líderes más importantes del PAT, y promotor de tan singular movimiento, destaca que no representó mayor problema organizar a los peones de las haciendas:

En casi todas las haciendas de los distritos de Huamantla, Apizaco y parte de Calpulalpan, estaban ya organizados los peones acasillados, gracias al tesonero esfuerzo de un humilde y valiente vecino de Atezcatzinco, creo que era maestro de escuela, el que con otros dos compañeros se reveló un magnífico organizador, cuyo nombre siento de veras haber olvidado, paréceme que se apellidaba Vázquez. A él se encomendaron los preparativos y la persuasión a los peones; ese hombre recorría las fincas día y noche, llevando en su morral por toda arma una Constitución de la República y millares de volantes impresos con esta leyenda: Constitución de 57. Artículo 5o: Ninguna persona está obligada a prestar servicios sin su pleno consentimiento y justa retribución. ${ }^{4}$

Los volantes circularon de manera profusa. Se colocaban en los muros de casas de los poblados y de las haciendas, pendian de los árboles en los caminos y en los campos se fijaban en las pencas de los magueyes. Como en la mayoría de los casos los peones no sabían leer, se les transmitía verbalmente este artículo de la Constitución para que lo aprendieran de memoria. ${ }^{5}$

\section{Nubarrones sobre el campo tlaxcalteca}

Próspero Cahuantzi, el gobernador porfirista de Tlaxcala, se derrumbó a finales de mayo de 1911, después de haber permanecido en el poder por más de 27 años. Dejó la gubernatura en forma transitoria en las manos de varios miembros de las clases dominantes, entre quienes destacaban Diego L. Kennedy y Agustín Sánchez. Pero se trataba de gobernadores interinos, quienes junto con otros personajes no menos prominentes duraban alrededor de medio año.

En forma acorde a la caída de la dictadura, se advertía una situación de abierto malestar en varias haciendas. Los trabajadores semaneros y

4 Porfirio del Castillo, Puebla y Tlaxcala en los días de la revolución, México, edición del autor, 1953, p. 100-101.

5 Loc. cit. 
luego los acasillados levantaron ámpula con la mira de remediar su tradicional situación de explotados. Curiosamente, la estrategia no consistía en destroncar a la oligarquía agraria mediante el reparto de la tierra, sino en la búsqueda de mejores condiciones de vida. Tampoco cuestionaban su condición de trabajadores temporales ni de trabajadores serviles. Su lucha se orientaba a que les fueran aumentados los sueldos, y al mismo tiempo reducidas las horas de trabajo. Fue justo durante el mes de septiembre de 1911, cuando se vislumbraron los primeros barruntos de inconformidad. Los encargados de las haciendas Mazaquiahuac y El Rosario, propiedad de la familia Solórzano Sanz, le comunicaron al administrador general residente en la ciudad de México, que los semaneros exigían "que se les disminuyeran las tareas de segadura". 6 Como en principio los encargados se habían opuesto a tan inauditas pretensiones, sin más ni más los semaneros se les separan de las haciendas. ${ }^{7}$ Antonio Castro Solorzano, administrador general, percibiendo los vientos renovadores del maderismo, responde textualmente que "está bien que no se haya sentado precedente de establscer costumbres que alteren el orden establecido en los trabajos de la finca a una moción injusta de los peones, pero hay que tener en cuenta y conciliar hasta donde sea posible". 8 Sabía que si se cerraba el diálogo con los semaneros, la cosecha se podría perder por la carencia de brazos. Existía ciertamente una fórmula alternativa para no ceder a los caprichos de los semaneros, pero no había tiempo para ponerla en funcionamiento. Se trataba de "substituir los semaneros que se fueron por peones acasillados". ${ }^{2}$

Como Antonio Castro no deseaba llegar a un enfrentamiento radical con los semaneros imparte directrices generales a los encargados de las dos haciendas. La respuesta va en el sentido de que si bien eran de lamentarse las exigencias de los peones, la verdad de las cosas es que los necesitaban con urgencia "y esto hace que tengamos necesidad de conciliar hasta donde sea posible esas exigencias con la conveniencia de los intereses". ${ }^{10}$ Justo el 24 de septiembre de 1911 pone sendos telegramas a los encargados de las haciendas, redactados en los términos siguientes: "Si fuera necesario acceda exigencias peones. Procure evitar prudentemente disminución de trabajadores."11

Durante la dictadura porfirista, esta clase de movimientos eran aplacados a sangre y fuego, pero ahora las cosas empezaban a cambiar. A ello se agregaba el terrible virus del socialismo. Antonio Castro advierte que se habían

esparcido infinicad de socialistas que andan instigando a los trabajadores por todas partes al amparo de la malhadada revolución. Ya les toco su turno a Mazaquiahuac y El Rosario de la manera siguiente: el lunes de la semana pasada exigieron los semaneros que la tarea de cortes de cebada se redujese a 15 varas en vez de 25 que se les daba antes y 20 después. Don Alejandro no accedio yéndose como 20 semaneros, pero puso a todos los trabajadores acasillados,

6 Antonio Castro Solórzano a Alejandro Sáinz, septiembre 21 de 1911, en la Universidad Iberoamericana, Archivo de las haciendas de Tlaxcala, 1.1.11.28, p. 25.

7 Loc. cit.

8 Loc. cit.

9 Lac. cit.

10 Antonio Castro Solórzano a Alejandro Sáinz, septiembre 25 de 1911, en la Universidad Iberoamericana, Archivo de las haciendas de Tlaxcala, 1.1.11.28, p. 30.

11 Loc. cit. 


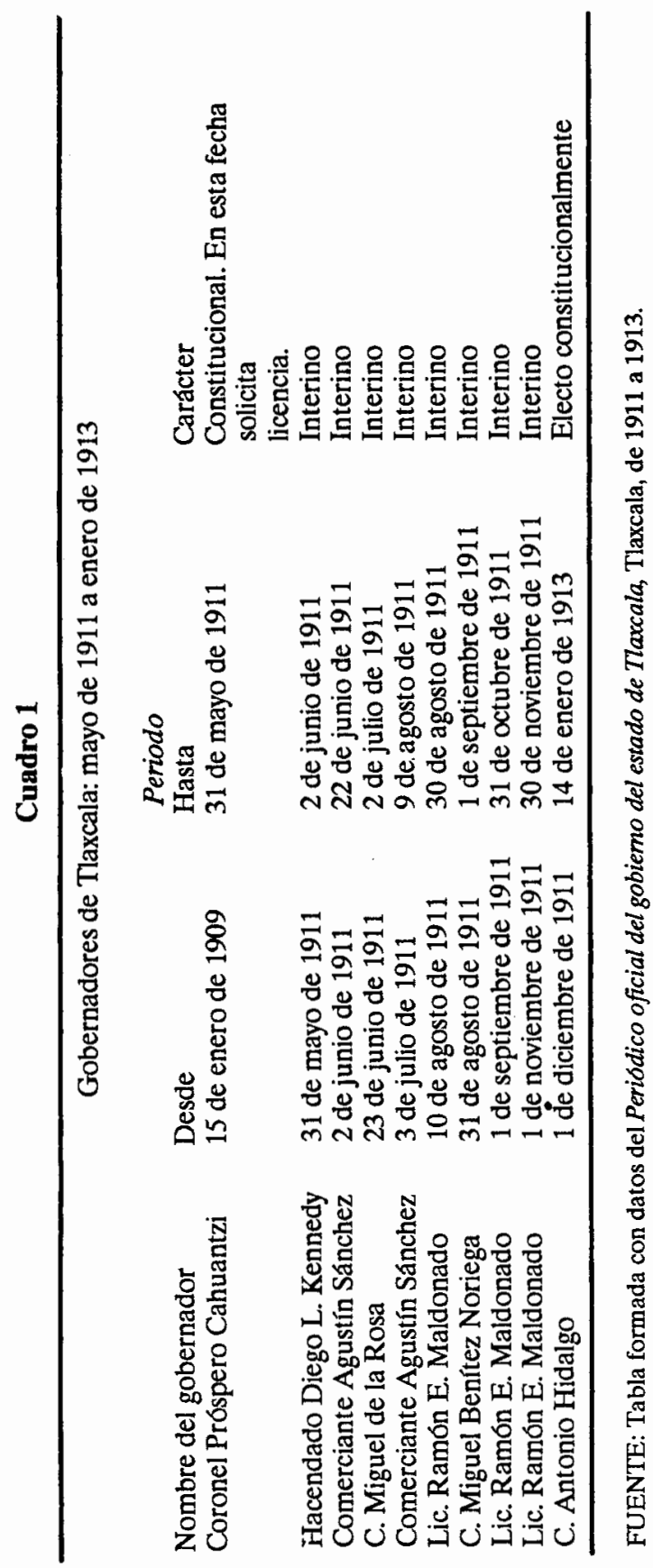


carboneros, carreros, a violentar el corte y así estuvieron toda la semana. Don Trinidad no pudo hacer lo mismo y accedio con sus exigencias. ${ }^{12}$

Esta rebelión de los semaneros se extiende a las haciendas de Xalostoc y de Tepeyahualco. Sus propietarios se vieron obligados a acudir ante las autoridades para que metieran en orden a sus huestes, pero sólo consiguieron que éstas determinaran "que los peones trabajaran por día y no por tarea, lo que sale más costoso". ${ }^{13}$ Bajo esta óptica, los hacendados quedan atrapados en una terrible disyuntiva: acceder a las peticiones de los semaneros o quedarse sin brazos para levantar sus cosechas. Pero el malestar social se complica en los días siguientes. Si bien en la mayor parte de los casos los hacendados ceden a las presiones de los semaneros, una suerte de efecto de demostración se consuma, ya que ni tardos ni perezosos los peones acasillados exigen lo mismo. Se sabe por boca de Antonio Castro, que en los primeros días de octubre de 1911:

En El Rosario cundió la propaganda perniciosa y los peones acasillados que después de que se fueron los semaneros por no ceder a sus exigencias, habían estado trabajando tranquilamente, se sublevaron la semana pasada rehusandose a trabajar si no se les daba la tarea de sólo 15 varas. Don Alejandro acudió a las autoridades de Tlaxco y después de algunas investigaciones se descubrió que el principal de los instigadores era el maestro de escuela a quien se llevaron a Tlaxco, teniendo al fin que accederse para no perder el tiempo ni exponerse a males mayores, a que la gente volviera al trabajo con 15 varas de tarea que es demasiado caro; parece que ya están tranquilos y tenemos esperanzas de que no se vuelvan a insubordinar con la extirpación del gérmen principal. En Mazaquiahuac hubo también un motincito, pero don Trinidad logró que los semaneros recibieran 15 varas y los acasillados 20 y 18 según el estado de las sementeras. ${ }^{14}$

Este despertar de los peones acasillados y de los semaneros, ya no se podría detener. Es más, ahora ya no sólo era impulsado por los dirigentes del PAT, sino también por algunos miembros del clero católico extranjero. Concretamente, un cura alemán, miembro de una congregación asentada en Puebla, y portađor de ideas progresistas, provoca el espanto de Antonio Castro. En un informe que rinde a los dueños de las haciendas radicados en Europa, les expresa:

A propósito, el jueves de la semana pasada, que fui a las dos haciendas, con el perito hidráulico, me volví a encontrar ahí con el Padrecito que había ido a despedirse porque mandan a su comunidad hasta Estados Unidos, pues parece que en Puebla no les dio resultado el establecimiento y, qué te parece, me encontré con que dicho padrecito tiene algo de ideas socialistas, pues entre lo mucho que hablamos me salió con que la gente de las haciendas estaba muy mal pagada y que los hacendados ganaban mucho dinero a costillas de los pobres e ignorantes trabajadores que eran como animales por lo rudo de sus tareas y por el trato que se les daba, que se les debía aumentar el jornal y ponerles escuelas tanto para hombres como para mujeres para ilustrar a todos. ${ }^{15}$

12 Antonio Castro Solórzano a José Solórzano Sanz, 26 de septiembre de 1911, en la Universidad Iberoamericana, Archivo de las haciendas de Tlaxcala, 1.1.11.28, p. 31.

13 Ibidem p. 32.

14 Antonio Castro Solórzano a José Solórzano Sanz, 2 de octubre de 1911, en la Universidad Iberoamericana, Archivo de las haciendas de Tlaxcala, 1.1.11.28, p. 41.

15 Antonio Castro Solórzano a José Solórzano Sanz, 30 de octubre de 1911, en la Universidad Iberoamericana, Archivo de las haciendas de Tlaxcala, 1.1.11.28, p. 102. 
Observación que de ninguna manera parece objetiva al administrador. Para éste, en Tlaxcala los peones vivian prácticamente en una situación paradisiaca que ya quisieran inclusive los ricos: “... ya quisieran en otras haciendas recibir el buen trato que en las de acá, a donde se les atiende como a hijos de Dios, proporcionándoles toda clase de auxilios espirituales, médicos, medicinales, escolares, y que lo del dinero era lo de menos, porque sólo les servía para fomentar vicios y nada más y ningún bienestar, que ellos en su humildad lo disfrutaban como las clases más elevadas ya quisieran". ${ }^{16}$ Punto de vista con el cual empezaban a ya no comulgar los peones acasillados ni los semaneros. Prueba de ello lo era el movimiento de rebelión. Ellos se daban cuenta de que no era justo que mientras trabajaban de sol a sol, los propietarios de Mazaquiahuac y El Rosario disfrutaran de la vida plácidamente en París, Roma, Florencia, etc. Por supuesto que los peones no aspiraban a llevar un estilo de vida similar, pero sí a que les fueran aumentados los jornales y reducidas las horas de trabajo. La máxima divina de que los criados, es decir, los empleados y sirvientes, desde el de mayor categoría hasta el de la última, deberían de servir a los amos como quien sirve a Dios, ${ }^{17}$ ya no les convencía del todo. Ansiaban una situación terrenal más justa y humana. Por siglos habían servido a los amos como al propio Dios y como resultado sólo habían recibido golpes, explotación y su conversión en esclavos por deudas.

\section{Antonio Hidalgo en el poder}

Al momento de realizarse las elecciones para encontrar a la persona que cubriera el periodo inconcluso de Cahuantzi, el PAT gana la gubernatura por intermedio de un antiguo obrero textil, Antonio Hidalgo; con este triunfo se consuma la avanzada del maderismo en la entidad. Hidalgo tenía que gobernar Tlaxcala durante un periodo que corría del 1 de diciembre de 1911 hasta el 15 de enero de 1913, algo así como trece meses y medio. Como se podrá advertir, su periodo de gobierno, no obstante que es demasiado corto, resulta ser a la postre uno de los más convulsos. Se debe advertir que tanto la oligarquía agraria como los industriales textiles quedaron sorprendidos con el triunfo de Antonio Hidalgo. A causa de ello desatan una feroz campaña de desprestigio, lo boicotean en forma sistemática e incluso lo incriminan en supuestas tentativas de transgresión del orden constitucional.

El PAT, que había ganado la gubernatura, acelera su labor redentora en beneficio de las clases populares. Contra viento y marea refuerza su política de defensa de los campesinos llegando al grado de incitarlos a la huelga. Por supuesto que la reacción del gobierno federal, en perfecta concordancia con la oligarquía agraria, fue opuesta a tales directrices. Desde el principio, el gobierno federal, atemorizado por el curso de los acontecimientos en Tlaxcala, dispone que el gobernador desactivara tales movimientos para impedir que se convirtieran en ejemplo para los peones de otras entidades. Madero de ninguna manera estaba dispuesto a embarcarse en una aventura política transformadora que rompiera con los marcos de la dominación oligárquica.

Al momento de asumir el poder, Hidalgo tiene la cortesía de hacérselo saber a cada uno de los hacendados de la entidad. Lo que buscaba era 
gobernar contando con el beneplácito de quienes de hecho eran el núcleo de las clases dominantes. Su comunicacion llega en fechas distintas a sus destinatarios. Por ejemplo la enviada al administrador de Mazaquiahuac y El Rosario llega hasta el 22 de diciembre de 1911, cuando Hidalgo ya había tomado posesión. La comunicación constituye un llamado a los hacendados para que coadyuvaran a la buena marcha de la administración. A cambio de ello, Hidalgo les prometía "atender toda indicación justa, dentro de sus facultades". ${ }^{18}$

\section{Primera ola huelguística en enero de 1912}

Con el paso de los días, el malestar de los peones acasillados y de los semaneros era cada vez mayor. Al despuntar el año de 1912 el campo estaba a punto de explotar. Lalabor conjunta de los dirigentes del PAT y de distintos líderes antirreeleccionistas, de nombre Vázquez, Marcelo Ramírez, Arturo Serrano y otros, facilita el alzamiento de los campesinos en diversos puntos de la entidad. A pesar de que Antonio Hidalgo tenía que tomar en cuenta los intereses de los hacendados, no podía ocultar sus simpatías en la aplicación de una política de índole social. Raymond J. Buve destaca que el gobernador era partidario de la reglamentación de la jornada laboral de ocho horas y de la substitución del tradicional sistema de pago a destajo por uno basado en un sueldo diario fijo, además de que siempre mostró una aversión hacia el sistema de esclavitud por deudas. ${ }^{19}$

Como de hecho el malestar de los campesinos manifestado en septiembre de 1911 no había cesado, los hacendados acudieron ante Madero para solicitarle refuerzos militares que defendieran sus propiedades. De paso le exigen que tomara una posición inflexible en contra de cualquier acción sospechosa de Hidalgo, después de que se convencen de que permitía a los dirigentes del PAT utilizar la imprenta oficial para imprimir folletos de tinte político para su distribución entre los trabajadores de los pueblos libres y de las haciendas. ${ }^{20}$ Cuando apenas despuntaba el año nuevo, un encabezado del diario maderista Nueva Era hace ver que el campo tlaxcalteca estaba en plena efervescencia, pues una huelga de labriegos había estallado causando confusión y desconcierto:

\footnotetext{
Se dice que los agricultores del Estado Tlaxcalteca están alarmadísimos por haberse declarado en huelga una gran parte de los peones de las fincas.

Hay algunos millares de peones, nos aseguran nuestros informantes, que abandonaron el trabajo y para reanudarlo exigen aumento de jornal.

Generalmente, los peones de campo han ganado en las fincas de Tlaxcala 25 centavos diarios, por la labor de un día natural, es decir, de las seis de la mañana a las seis de la tarde, con un intervalo de una hora para el almuerzo. Ahora, los peones huelguistas exigen un peso diario: pretenden principiar la tarea a las seis de la mañana, suspenderla a las doce y reanudarla a las dos, para terminar a las cinco de la tarde.21
}

18 Antonio Castro Solórzano al gobernador Antonio Hidalgo, 1 de enero de 1912, en la Universidad Iberoamericana, Archivo de las haciendas de Tlaxcala, 1.1.11.28, p. 207. 19 Raymond J. Buve, "Agricultores, dominación política y estructura agraria en la revolución mexicana: el caso de Tlaxcala (1910-1918)", en R. Buve (editor), Haciendas in central Mexico from late colonial times to the revolution, Amsterdam, CEDLA, 1984, pp. 219 220.

20 . Ibidem, p. 220.

21 "Labriegos en huelga en Tlaxcala", en Nueva Era, 5 de enero de 1912. 
Se trataba de que se negaban a trabajar las doce horas diarias, incluyendo la hora de descanso, y proponían en cambio trabajar sólo once incluyendo dos horas diarias de descanso. Según el corresponsal del mismo diario, los peones estaban en plan intransigente al grado de que "Tlaxcala nos pinta la situación alarmante y [...] de no buscarse una solución inmediata, la huelga agrícola podría cundir bien pronto e invadir otros estados, cuando menos los de Hidalgo y Puebla, limítrofes de Tlaxcala".22 Para el gobernador, quien apenas había iniciado un mes antes su mandato, la tarea consistía en manejar la situación con tino. Tenía que maniobrar en forma hábil para no verse inculpado directamente por el gobierno federal, ya que sus correligionarios eran en parte los responsables de meter fuego a la hoguera. Hidalgo no podía permanecer indiferente y dejar que las huelgas se extendieran incluso a otras entidades, con grave perjuicio para la tranquilidad del campo. En los días siguientes tiene un diálogo tanto con los hacendados como con los peones huelguistas, que en gran número acudieron a la capital del estado. ${ }^{23}$ Un cable difundido en la ciudad de Puebla y reproducido en Nueva Era el 9 de enero expresaba que

Por noticias que han llegado a esta ciudad se sabe que en algunas de las haciendas de Tlaxcala que se encuentran en los límites con este Estado, se han declarado en huelga los peones exigiendo que se les pague un peso diario y se reduzcan las horas diarias de trabajo a ocho. Los propietarios de las haciendas encuentran muy elevado el jornal que tratan de exigir los peones, y se han negado rotundamente a acceder a lo que se les pide. 24

Para el mismo diario, "la situación de los peones es muy comprometida, pues carecen de elementos para sostenerse". ${ }^{25}$ Pero si bien el diario maderista se cuidaba de atacar al gobernador de Tlaxcala, en el periódico El País, dirigido por el tlaxcalteca Trinidad Sánchez Santos, se incrimina directamente a Hidalgo al afirmar que "las haciendas de este rumbo están en huelga, porque pretenden los operarios mayor salario del que perciben diariamente, siendo el autor de estas huelgas el mismo Antonio Hidalgo, según noticias seguras que tengo, pues este señor pretende sacar de la convención de hacendados de todo el Estado que va a tener verificativo mañana en Apizaco, algún provecho". ${ }^{26}$ La reacción del gobernador fue inmediata. Textualmente expresa: "Protesto enérgicamente contra las aseveraciones que asienta dicho señor, de que soy el autor de las huelgas en que se han declarado los peones del campo. Como creo que tendrá usted persona digna como corresponsal de Huamantla, exijo pruebe esos cargos que me hace." 27 En contra de lo que se podía suponer, al corresponsal no se le ocurre cómo demostrar sus afirmaciones.

La prensa de la capital seguiría haciéndose eco de tan singular movimiento. En los días siguientes se dice que la huelga afectaba a nueve haciendas, sin afirmar que no se había extendido a otras más. Se trataba de las haciendas de Santo Domingo, Santo Tomás, San Isidro, Cualcoloya, Zetincla (sic), Santa Agueda, Santa Clara, San Antonio y Segu-

22 Loc. cit.

23 "Fue asaltada ayer la hacienda de La Trinidad", en El Imparcial, 9 de enero de 1912.

24 "Las haciendas de Tlaxcala sin peones", en Nueva Era, 9 de enero de 1912.

25 Loc. cit.

26 "Agitación en Huamantla, Tlaxcala", en El Pais, 13 de enero de 1912.

27 "El gobernador Hidalgo y las huelgas", en El Pats, 17 de enero de 1912. 
ra Michac. 28 Las huelgas no llegan a tocar a las haciendas de Mazaquiahuac y El Rosario. El administrador de éstas asegura que

Conocía ya el carácter alarmante que están tomando estas, no sólo en el Estado de Tlaxcala, y de los peones del campo, sino también de los operarios de varios talleres y fábricas. Esta es una plaga que, agregada al bandolerismo que ha surgido por toda la República, amenaza de una manera terrible la propiedad, que es el punto de mira al que converge este azote social, que no sabemos hasta dónde nos llevara. ${ }^{29}$

El mismo personaje afirma en los días siguientes que "por Tlaxcala nos anda llegando la lumbre de las huelgas de campesinos, habiendo reventado ya en algunas fincas de los llanos, con pretensiones de ganar 75 centavos y hasta $\$ 1.00$ diario". 30 Evidentemente que las huelgas no llegan a estallar en tales haciendas a causa de que el administrador optó por manejar la situación cediendo a las pretensiones de los peones y de los semaneros. Además de que no comulgaba plenamente con hacendados como Ignacio Torres Adalid y Vicente Sánchez Gavito, quienes estaban dispuestos a arrollar no sólo a los peones huelguistas sino al propio gobernador.

Si bien es cierto que los peones acasillados y semaneros no llegan a estallar la huelga en las 146 haciendas, lo que sí es un hecho es que provocan una fuerte convulsión en el campo tlaxcalteca. En un principio, los peones enarbolan banderas que se limitaban a exigir tanto la reducción de las horas de trabajo como el aumento de los salarios, pero con el paso del tiempo el movimiento se complica. Los peones acasillados toman conciencia de que les era impostergable romper con las cadenas que los ataban a la hacienda, cuestión que sólo se podía lograr mediante la derogación de la vieja ley expedida en 1882, y que de hecho los mantenía en calidad de esclavos. Por supuesto que esto último era una bandera trascendental. La cuestión de la abolición de los castigos físicos, de la esclavitud por deudas, de la imposibilidad de abandonar las haciendas - sin liquidar en forma previa sus deudas, entre otras restricciones, se vuelven más candentes.

\section{La junta de hacendados en Apizaco y la fundación de la Liga de Agricultores}

La labor de agitación desplegada por el PAT entre los peones acasillados y los semaneros, produce dos efectos inmediatos. Uno de ellos es que orilla a los hacendados a cerrar filas. El 12 de enero de 1912 se reúnen en la ciudad de Apizaco alrededor de 200 hacendados con la mira de fundar un organismo político que les sirviera de punta de lanza para defender sus intereses de clase. Se trata de la Liga de Agricultores. ${ }^{31}$ El otro consiste en que se dan cuenta de que no podían seguir actuando en forma autoritaria para doblegar a los peones acasillados y semaneros, y que era necesario negociar. En virtud de ello dictan nuevas medi-

28 "Los huelguistas de Puebla y Tlaxcala ante el señor Presidente", en El Imparcial, 14 de enero de 1912 .

29 Antonio Castro Solórzano a Trinidad Mateos Furlong, 18 de enero de 1912, en la Universidad Iberoamericana, Archivo de las haciendas de Tlaxcala, 1.1.11.28, p. 231.

30 Antonio Castro Solórzano a José Solórzano Sanz, 22 de enero de 1912, en la Universidad Iberoamericana, Archivo de las haciendas de Tlaxcala, 1.1.11.28, p. 240.

31 "Hubo una importante reunión de hacendados en Apizaco", en El Imparcial, 12 de enero de 1912 . 
das de índole laboral, con la única salvedad de que tenían que ser homogéneas y respetadas por todos ellos:

La Liga se mostro capaz de implantar en Tlaxcala un sistema uniforme de rayas para los trabajadores del campo, eliminando así la competición entre los propietarios y restringiendo la movilidad horizontal de los peones y trabajadores. Para mantener el orden público y reprimir posibles brotes de actividad revolucionaria, la Liga presionaba al Gobierno federal para que reforzara el aparato militar. El regreso del Cuerpo Rural, la compra de armas y el constante refuerzo de guardias rurales tenían que asegurar el orden en el campo. ${ }^{32}$

La Liga de Agricultores de ninguna manera tocaba la ley de 1882 que legitimaba el trabajo esclavo, pero a los hacendados asistentes a la junta de Apizaco, envueltos en el torbellino huelguístico, también les interesaba abordar otros asuntos. En principio, se quejan amargamente del bandolerismo, ya que sin más ni más "los bandoleros se enseñorean de las fincas, hasta el grado de que cuando lo tienen a bien, entran en partidas de veinte o más hombres y sin pedir permiso a nadie, se ponen tranquilamente a pizcar, robándose las semillas". 33 Por lo demás, afirmaban que hacía más de quince días "que por la huelga de los peones, no se riegan los terrenos, y está echándose a perder el trigo. Además, aseguran que algunas autoridades de Tlaxcala han enviado comunicaciones a los campesinos, ordenándoles suspendan todas sus labores en las fincas". ${ }^{34}$ Como eran demasiados problemas, en la junta de Apizaco acuerdan que una comisión de hacendados se trasladara a la ciudad de México a conferenciar con el presidente de la República. ${ }^{35}$ Paradójicamente, para el administrador de Mazaquiahuac y El Rosario la cosa en realidad no era tan grave. Si bien las huelgas eran un hecho indudable, en el fondo se mezclaban toda clase de ambiciones políticas. Es más, la junta de Apizaco, "por más que aparezca que [...] reviste un carácter agrícola solamente, no deja de perseguir sus fines políticos, cosa que no deja de tener sus inconvenientes". ${ }^{36}$ Pero, además, le resulta sorprendente la afirmación del corresponsal de El País, de que "el mismo gobernador sea el agitador de las huelgas [ya que] puede ser no sólo aventurada calumnia sino calumniosa". ${ }^{37}$ Pero aun aceptando que la situación fuera grave en Tlaxcala, para el citado administrador lo mejor era mantenerse al margen ya que estaba de por medio una vendetta entre los más prominentes hacendados y el gobernador. Para finalizar, los 200 hacendados reunidos en Apizaco eligen una mesa directiva compuesta de personalidades como Ignacio Torres Adalid, quien fue electo presidente. Su tarea principal consistía en convencer a todos los hacendados de que

32 Raymond 'J. Buve, op. cit, p. 220; Margarita Menegus Bornemann y Juan Felipe Leal, Los trabajadores de las haciendas de Mazaquiahuac y El Rosario, Tlaxcala, en los albores de la revolución agraria: 1910-1914, México, Facultad de Ciencias Políticas y Sociales-UNAM (mimeografiado); y de los mismos autores, "Las haciendas de Mazaquiahuac y El Rosario en los albores de la revolución agraria", en Historia M exicana, México, El Colegio de México, No. 112, 1981, pp. 233-277.

33 "Hubo una importante reunión de hacendados en Apizaco", en El Imparcial, 12 de enero de 1912.

34 Loc. cit.

35 Loc. cit.

36 Antonio Castro Solórzano a Trinidad Mateos Furlong, 18 de enero de 1912, en la Universidad Iberoamericana, Archivo de las haciendas de Tlaxcala, 1.1.11.28, p. 231.

37 Loc. cit. 
tenían que respetar la nueva disposición consistente en que los jornales serían en lo futuro de 60 centavos diarios, la supresión de las raciones de maíz y lo que llaman "condonar abonos de cuentas". 38

Para Antonio Castro, la junta de Apizaco difícilmente podría arrojar resultados prácticos, a causa de que los dirigentes de la Liga de Agricultores buscaban ante todo sus conveniencias personales. Esto es, meter mano en asuntos políticos como elecciones de autoridades, de diputados, etc. Es más, en forma sorprendente afirma otra vez que la verdadera causa del movimiento de los peones acasillados y de los semaneros era el fenómeno del socialismo. Y lo peor era que nadie podía prever hasta dónde llegaría el llamado "socialismo, ya que está tomando formas alarmantes en nuestro desgraciado país". 39 Afrontar este problema no era fácil a causa de que no sólo el gobierno federal sino el local eran socialistas: "La gente anda muy soliviantada y hay rumores de que exigirán jornales de un peso diario y menos horas de trabajo, con la circunstancia agravante de que el Gobierno en general y en particular el gobernador de Tlaxcala, que es esencialmente socialista, de las capas bajas, los apoyan y tiene que apoyarlos para sostener su popularidad". 40

\section{El asalto de las haciendas}

Al problema de las huelgas de los peones se suma el del bandolerismo. El diario El País del 17 de enero de 1912 asegura que al grito de iViva Zapata! los bandoleros saquean e incendian el pueblo de Zacatelco. Ocho haciendas del fértil valle de Nativitas siguen el mismo destino:

Después de convertir al pueblo de Zacatelco en ruinas y despojar a sus habitantes de cuanto tenían, sembraron en todas partes la desolación y el espanto; los bandoleros zapatistas se dirigieron sobre las haciendas del Valle de Nativitas y saquearon ocho fincas, entre las que se cuentan Santa Ana Portales, propiedad de los sefiores Caso y Santiago Michac, y otra de los seffores Morales Conde. ${ }^{41}$

Acto seguido, los enardecidos zapatistas toman y saquean la hacienda de Santa Elena, propiedad de Baldomero Rejón. ${ }^{42}$ Pero en esta última hacienda ocurre un hecho inesperado: mientras los empleados trataban de hacer resistencia a los bandoleros, los peones de la finca se suman a las fuerzas zapatistas. El resultado es que los defensores de la finca fueron batidos. Por supuesto que además la finca fue saqueada. ${ }^{43}$ Un día después corre la misma suerte la hacienda de Tetla. ${ }^{44}$ Pero los destrozos no paran ahí, ya que la hacienda de San Miguel del Molino, propiedad de Alvaro Fernández y ubicada dentro del estado de Puebla,

38 Antonio Castro Solórzano a José Solórzano Sanz, 29 de enero de 1912, en la Universidad Iberoamericana, Archivo de las haciendas de Tlaxcala, 1.1.11.28, p. 257.

39 Antonio Castro Solórzano a José Solórzano Sanz, 5 de febrero de 1912, en la Universidad Iberoamericana, Archivo de las haciendas de Tlaxcala, 1.1.11.28, p. 268.

40 Antonio Castro Solórzano a José Solórzano Sanz, 12 de febrero de 1912, en la Universidad Iberoamericana, Archivo de las haciendas de Tlaxcala, 1.1.11.28, p. 279.

41 "Al grito de iViva Zapata! los bandoleros saquearon e incendiaron el pueblo de Zacatelco", en El Pais, 17 de enero de 1912.

42 Lac. cit.

43 Loc. cit.

44 "Zapatistas cerca de Nativitas", en El Pais, 18 de enero de 1912. 
también es saqueada. ${ }^{45}$ La hacienda Santa Agueda, propiedad de los Morales Conde, sufre un robo de trigo y de paso los zapatistas hieren a un empleado. ${ }^{46}$ Pero habría otro elemento de indignación para los hacendados: el hecho de que existieran gentes dedicadas a instigar a los trabajadores para que abandonaran sus labores. La prensa diría que "Esta mañana fue expulsado uno de estos infames agitadores de la hacienda de Santa Agueda". ${ }^{47}$ Como parte de la misma secuela de bandolerismo, es asaltada la hacienda de San Antonio Michac, también del Valle de Nativitas, y su administrador, herido. ${ }^{48}$

Por supuesto que en el el ínterin Antonio Hidalgo recibió indicaciones del gobierno federal para que pusiera en orden las cosas en su entidad, mientras que, por su parte, tomaba las medidas pertinentes del caso para hacer frente a la ola de asaltos a las haciendas. En principio suspende las garantías individuales en varios estados del México central, justamente donde el zapatismo había prendido y provocado la alarma entre los hacendados. Las medidas del gobierno federal rinden los frutos esperados ya que ceden tanto las huelgas comos los asaltos de las haciendas.

\section{Segunda ola huelguística}

Pero la calma que aparentemente reina en el campo tlaxcalteca durante unos siete meses llega a su fin. La labor de agitación del PAT en las haciendas alcanza otra vez su punto álgido, justo en el momento en que los hacendados tratan de derrocar por la vía legal al gobernador. Es entonces que los peones acasillados le sirven a Hidalgo como bastión de apoyo para enfrentarse en forma abierta a la oligarquía y estalla una segunda oleada de huelgas en Tlaxcala. Pero entonces los peones acasillados ya no manejan tanto el problema del aumento de salarios o de reducción de las horas de trabajo, sino que cuestionan abiertamente la vieja ley de 1882 que los tenía convertidos en esclavos. Los peones acasillados se resisten a trabajar en tanto no fuera modificada tan diabólica ley. Para los semaneros la lucha sería más fácil, ya que como no estaban atados a las haciendas por deudas seculares, en cualquier momento las podían abandonar. En concreto, conforme pasaba el tiempo, era evidente que crecía la hostilidad entre el gobernador y los hacendados. Es más, estos últimos se convencían cada vez más que las autoridades locales eran demasiado complacientes con la postura rebelde de los peones agrícolas. Las cosas llegaron al grado de que dos prominentes miembros de la oligarquía presentaron una formal acusación en contra del gobernador pidiendo su destitución. El congreso del estado erigido en Gran Jurado a principios de septiembre de 1912, delibera en forma secreta acerca de tal acusación, formulada por Ignacio Torres Adalid y Vicente Sánchez Gavito. ${ }^{49}$ Antonio Hidalgo sale absuelto, pero la acusación era el mejor testimonio de la hostilidad entre ambos. Precisamente en los días siguientes, estalla lo

45 “Combate en San Miguel del Molino", en El Pats, 19 de enero de 1912.

46 Loc. cit.

47 Loc. cit.

48 Loc. cit.

49 "El gobernador Hidalgo acusado fue absuelto por la legislatura que se erigió en Gran Jurado", en El Imparcial, 5 de septiembre de 1912; y "El señor gobernador de Tlaxcala ha sido absuelto", en La Patria, 5 de septiembre de 1912. 
que sería la segunda oleada huelguística en el campo tlaxcalteca. Para Raymond J. Buve

[...] los dirigentes del PAT, y sobre todo los líderes de Zacatelco y Xicohtzingo, organizan otra huelga durante el verano del mismo año. Esta otra huelga también se origino en la cuenca del río Atoyac. Una petición impresa y ampliamente distribuida en la que se exigían mejores condiciones laborales fue presentada al Presidente Madero. Aunque no se conocen cifras exactas, es generalmente aceptado entre los autores locales que la huelga ciertamente no se confinó a las haciendas que rodean la ciudad de Tlaxcala, sino que se extendio a las haciendas de los distritos del norte completamente dominados por los hacendados. Los terratenientes tlaxcaltecas por su parte, lograron convencer al gobierno federal del peligro que involucraba una huelga en zonas cercanas al zapatismo. 50

El movimiento trata de ser acallado a causa de que se temía que pudiera servir de aliciente a los peones acasillados de las haciendas de entidades vecinas. No obstante el celo con que es manejado el problema, éste logra ser captado en la capital de la república. El diario El Imparcial del 9 de septiembre, expresa que algo raro estaba pasando con los peones de la cercana entidad. Sin aceptar que se trataba del estallamiento de una huelga, expresa que "los peones de las haciendas de Huamantla que desaparecieron [...] y que se decía que iban a unirse con los rebeldes, volvieron hoy al trabajo, pues solamente fueron a hablar con el gobernador de Tlaxcala, para pedirle aumento de jornales". 51 Ún día después, el diario Nueva Era era más claro y expresaba que había estallado una huelga de peones acasillados en algunas de las haciendas del distrito de Huamantla:

El día 8 del corriente, hubo alarma en esta población con motivo de que los peones de las haciendas del distrito se presentaron en huelga, siendo los principales los de Baquedano, propiedad del señor licenciado Miguel Torreblanca; Tecoac, del Señor Gustavo Bretón, y San Pablito, del señor Feliciano Rivera. El prefecto político, señor Joaquín de la Barreda, salio hoy para los sitios mencionados y felizmente cbiuvo la paz y sin intervención de la fuerza calmo totalmente la situación que se iba empeorando. 52

Temiendo que el movimiento se generalizara en las 146 haciendas, los propietarios sin la menor vacilación acuden al gobierno federal. A causa de la abierta hostilidad que existía entre ellos y el gobernador, no tenía sentido acudir a él exigiéndole que pusiera fin a tales movimientos. Como las autoridades federales estaban al tanto del continuo ambiente de agitación surgido en el campo tlaxcalteca, de inmediato le solicitan informes al gobernador. En principio les interesaba saber si el movimiento se había extendido a más haciendas de las reportadas por las fuentes periodísticas, quiénes eran los instigadores o responsables y, finalmente, si había sido controlado o no el movimiento de huelga. Antonio Hidalgo le contesta al secretario de Fomento el mismo dia en que había sido requerido, en el sentido de que efectivamente había estalla-

50 Raymond J. Buve, op. cit., p. 221.

51 "Quieren aumento de jornales. Peones de las haciendas de Tlaxcala y Puebla hacen pacífica gestión", en El Imparcial, 10 de septiembre de 1912.

52 "Huelga de obreros", en Nueva Era, 13 de septiembre de 1912. 
do una huelga de peones, pero que ella no había alcanzado dimensiones que rebasaran su capacidad de control. En forma escueta le hace saber que, de acuerdo con los informes aportados por el prefecto político de Huamantla:

... me honro en participar a usted que hecha la averiguación correspondiente para inquirir los motivos de ciertos movimientos huelguísticos efectuados por peones de haciendas de este Distrito, resulta que dichos movimientos han sido espontáneos, pues que interrogados convenientemente los peones de las haciendas de San Pablito y Tecoac, únicos que a esta Prefectura consta que tenían ciertas desaveniencias con sus patrones, las cuales fueron ya solucionadas satisfactoriamente para ambas partes, aquéllos afirman enérgicamente que nadie los instiga para que así obren más que la razón que creen tener. ${ }^{53}$

Pero habría varias cuestiones que llaman la atención en la versión del gobernador. Una de ellas es que sólo acepta que la huelga había estallado en dos haciendas, cuando las fuentes periodísticas señalaban tres. La otra es que el gobernador se cuida de no mencionar que entre sus correligionarios del PAT se encontraban los instigadores de la movilización campesina.

Como los hacendados no habían tenido éxito en su plan de derrocamiento del goberndor, traman otra peregrinación hacia la capital de la república para entrevistarse con el secretario de Gobernación. El grupo principal de hacendados era originario de Tlaxco, y de ninguna manera estaba dispuesto a seguir tolerando las huelgas de.los peones acasillados y de los semaneros, como tampoco los continuos brotes de rebelión. Para el administrador de Mazaquiahuac y El Rosario, esta marcha hacia la capital del país simplemente se debía a simples "intrigas políticas de Sánchez Gavito y Cía." 54 Pero la anunciada marcha de protesta de los hacendados, no fue lo numerosa que se esperaba ya que "sólo iban don Pepe González, Carranco y Merchand de cuyas fincas los peones se declararon en huelga". 55 A causa de la oposición del gobierno federal al estallido de las huelgas en las haciendas, el gobernador tiene que actuar para desactivar el movimiento. Pero casi a finales del mismo mes de septiembre se advierten otros brotes de rebelión entre los peones, sólo que estos movimientos no logran ser captados por la prensa de la capital de la república. Miguel González Durán, propietario del rancho de San Miguel Atenco, del distrito de Cuauhtémoc, sumamente alarmado se dirige al secretario de Fomento, haciéndole ver que un grupo de 16 peones acasillados se le habían puesto en huelga. Pero lo realmente grave era que los peones, en lugar de tratar con él, acudieran ante las autoridades locales. El hacendado expresa que:

... sin motivo justificado, a principios de la semana retropróxima en número de diez y seis jornaleros, que reportamos de año, se declararon en huelga pacífica, presentándose ante la autoridad política de este Distrito, alegando no sé qué causas o motivos que justificaran su procedimientos; el caso es que ante

53 "El C. Gobernađor del estađo de Tlaxcala, en oficio número 7932 fecha 10 de los corrientes me dice lo que sigue. Al C. Secretario de Fomento", México, 13 de septiembre de 1912, en el Archivo General de la Nación, Ramo Trabajo, caja 11, expediente 24.

54 Antonio Castro Solórzano a José Solórzano Sanz, 16 de septiembre de 1912, en la Universidad Iberoamericana, Archivo de las haciendas de Tlaxcala, 1.1.11.29, p. 234.

55 Antonio Castro Solórzano a José Solórzano Sanz, 23 de septiembre de 1912, en la Universidad Iberoamericana, Archivo de las haciendas de Tlaxcala, 1.1.11.29, p. 248. 
dicho funcionario se levantó una acta, cuyo contenido no se me quiso decir, obligándoseme a que firmara otra, en que dijera mi pensar respecto de la actitud de mis dependientes, a lo que contesté y la Secretaría de dicha Prefectura afirmó por escrito, que no obstante el compromiso estipulado de la obligación que pesa sobre ellos de sacar el affo agricultor trabajando conmigo con las labores del campo, y no obstante también los perjuicios que se me seguían con suspender la etapa dctual del trigo, e interrumpir la siega próxima de la cebada, me era indiferente su separación, exigiendo solamente que se me asegurara, a satisfaccion, el adeudo respectivo de cada individuo, cuyo total importa sobre mil quinientos pesos. ${ }^{56}$

Las autoridades locales, a las que finalmente acude el hacendado, le aseguraron que su asunto tendría una solución rápida, la cual le comunicarían. Como el tiempo pasaba y no le llegaba la ansiada solución, solicitó el auxilio del gobierno federal. Con ello buscaba, por una parte, poner en evidencia la postura pasiva del gobernador, y por otra, exigir que le fuera solucionado su problema:

Esto ocurrio el 30 de septiembre próximo pasado, y cada día que pasa, personalmente o por conducto de tercera persona, pregunto el resultado de este asunto, y a pesar del tiempo transcurrido ninguna solución se recibe. Esta moratoria, como es de comprenderse, está ocasionándome graves perjuicios por la suspensión de los respectivos trabajos que siguen sin ejecutarse a medida del tiempo y de lo que la sementera requiere. Tal omisión refluirá en graves perjuicios a mis intereses, y aun al Erario Público porque por la falta de elementos no podría subvenir al pago de esos impuestos. 57

Miguel González Durán aprovecha la oportunidad para denunciar ante la federación de que el promotor directo de tales huelgas era Bibiano Varquer, delegado del gobierno del estado de Tlaxcala. El era quién, $\sin$

... calcular los males trascendentales que origina, anda por varias fincas rústicas del Estado sugestionando a los dependientes e infundándoles pretensiones que deben tener en cuenta para regirse en lo sucesivo, a lo cual no habria dificultad, pero previo convenio con el propietario o administrador, y nunca bajo la forma que han adoptado, por los graves perjuicios que se resienten en cuyo caso me encuentro ahora. Mi súplica se reduce a que se prevenga al personal del Gobierno de este Estado para que resuelva desde luego lo que crea conveniente yequitativoa las diferenciasque para conmigo tienen mis dependientes, para quienes de parte mía, ha habido consideraciones, y para que influya también en que el adeudo del sirviente que al fin pretenda separarse, a satisfacción competente, asegure el adeudo que previa liquidación le resulte. 58

Pero la postura del hacendado encerraba un drama terrible para la suerte de los peones acasillados. Aceptaba otorgarles la libertad a condición de que le liquidaran la deuda que gravitaba sobre sus espaldas. En este caso, los 16 peones estaban obligados a cubrir nada menos que 93 pesos con 75 centavos cada uno si es que pretendian alcanzar su libertad. Reunir esta cantidad para los peones no era fácil. Según Eze-

56 "El C. Miguel González Durán de Apizaco en ocurso de fecha 8 del actual, dice a esta Secretaría lo siguiente. Al C. Secretario de Fomento", México, 11 de octubre de 1912, en el Archivo General de la Nación, Ramo Trabajo, caja 11, expediente 23.

57 Loc. cit.

58 Loc. cit. 
quiel M. Gracia y el diario Nueva Era, los salarios de los peones agrícolas de Tlaxcala eran de 25 centavos diarios. ${ }^{59}$ Nathan L. Whetten asegura que en 1910 el jornal promedio de los trabajadores agrícolas era de 51 centavos diarios; ${ }^{60}$ y desde enero de 1912 la Liga de Agricultores había recomendado a todos sus socios que pagaran un jornal diario de 60 centavos. 61 Si se toma como referencia el monto de los salarios fijados por la Liga de Agricultores, resultaba que para reunir los casi 94 pesos los peones necesitaban trabajar 156 días hábiles. Pero la cosa se complica si en realidad el salario era de tan sólo 25 centavos diarios, ya que entonces necesitaban trabajar 375 días hábiles para romper con su condición de esclavos por deudas. Esta cuestión demostraba que tanto Miguel González Durán como los demás hacendados sabían perfectamente bien que los peones que osaran participar en tales movimientos huelguísticos, buscando por este medio alcanzar su libertad, de todas formas no lo lograrían. Antes que nada tenían que pagar su deuda. Al final de cuentas los peones no tendrían otra alternativa que la de regresar a la hacienda sujetos a las mismas condiciones de trabajo y de explotación. Pretender abandonar la hacienda en forma intempestiva, sin cubrir sus adeudos, los exponía a ser acusados ante las autoridades como responsables del delito de fraude. Sobre esto era muy clara la ley de 1882 . Es por ello que la aspiracion de los peones de irse de la hacienda en el momento que lo desearan resultaba ser sólo un ansiado sueño.

\section{Un discurso dramático del gobernador}

De hecho, conforme pasaba el tiempo, Hidalgo y los dirigentes del PAT resultaban ser mucho más progresistas y revolucionarios que el propio Madero. Pero también los dirigentes de Tlaxcala se dan cuenta de que su política de redención de sus hermanos de clase no era bien vista. Que lo que pretendieran hacer en favor de los peones acasillados les podría acarrear toda clase de desventuras. A pesar de ello, Antonio $\mathrm{Hi}$ dalgo continúa remando en contra de la corriente. A estas alturas de su mandato sabía perfectamente bien que era casi imposible lograr la liberación de los peones, y que mientras no fuera derogada la fatídica ley de 1882 , ella seguiría operando en forma en extremo diabólica en contra de la suerte de los peones. En un discurso pronunciado el 5 de octubre de 1912, Antonio Hidalgo describe en forma drámatica que:

Los peones de campo de numerosas haciendas han estado acudiendo en demanda de protección contra vejaciones de que acusan a los dueños o administradores, como la de obligar a trabajar desde las 3.30 de la mañana hasta la puesta del sol, obligarlos a trabajar aun enfermos, aumentárseles sus tareas sin el proporcional aumento de jornal, recibir tratamientos ofensivos de palabra y de hecho, sufrir descuentos por su falta de asistencia a ceremonias del culto católico, y sufrir encierros en trojes o en las cárceles privadas que denominan "Tlapixqueras".

59 Ezequiel M. Gracia, Los tlaxcaltecas en la etapa revolucionaria, 1910-1917, Tlaxcala, Zavala, 1961, p. 32.

60 Datos de Los salarios agricolas en 1944, México, Secretaría de Agricultura y Fomento, 1946, p. 8,9 y 22, tomados de Nathan L. Whetten, "México rural", Problemas agrícolas e industriales de México, México, Vol. V, No. 2,1953, p. 187.

61 Ricardo Rendón Garcini, "La revolución agraria vista por el administrador de dos haciendas tlaxcaltecas (1910-1920)", en Raymond J. Buve (editor), op. cit., p. 278. 
Llano sería el remedio de tan aflictiva situación, a no mediar las circunstancias de reconocer casi todos los peones adeudos de cierta consideración a sus principales y existir una ley, por más que a juicio de personas entendidas, anticonstitucional, que pena como fraude la separación de un peón endeudado sin el consentimiento de su amo. ${ }^{62}$

A juicio del gobernador, dicha ley ameritaba su completa derogación o en el peor de los casos, una escrupulosa revisión. Pero el gobernador sabía que no sólo los hacendados se le opondrían de manera feroz, sino también el gobierno federal, y a causa de ello casi nada se podía hacer. Por si ello no fuera suficiente, su mandato estaba próximo a concluir y en el seno del congreso local encontraba cada vez más oposición a su política de índole social. Hidalgo analiza bien el curso probable de los acontecimientos y concluye que no le quedaba otra alternativa más que la de seguir una política ya de franca conciliación:

Hecha esta salvedad, manifestare que en cada conflicto de los anotados que se presentaron, he suscitado juntas conciliadoras esforzándome por restablecer en ellas la mejor inteligencia entre dependientes y patrones, y cuando las distancias se interponen, recomiendo empeñosamente a los Prefectos que adopten igual línea de conducta, y si la mediación amistosa de la autoridad no surte los efectos apetecidos, entonces los peones son exhortados a la vuelta al cumplimiento de sus obligaciones, pero entendidos de que comuniquen sin dilación cualquier atropello que experimenten, para que si cae bajo la sanción de la ley penal, como los golpes, los encierros en cárceles privadas, etcétera, se aplique sin dilación el correctivo que fuere de justicia. ${ }^{63}$

Pero de nada servía que los peones se quejaran de recibir maltratos o castigos de parte de sus patrones, ya que de todas formas no podían separarse de la finca. Por encima de sus quejas y lamentos, estaba la obligación de liquidar sus deudas. Al mismo tiempo, no tenía mucho sentido que la ley expresara que las autoridades cuidarían de su estricto cumplimiento. Con la excepción del periodo de gobierno del PAT, a las autoridades locales y federales jamás les interesó vigilar la conducta en extremo liberal y abusiva de los hacendados. Todo el mundo sabía de la existencia de las cárceles privadas en las haciendas, de que sus dueños impartían ahí "justicia" en abierta violación con las leyes, pero difícilmente las autoridades lo impidieron. Es por ello que la labor de Antonio Hidalgo y del PAT se erige en una suerte de esperanza para los peones en contra de tanta maldad humana. Antonio Hidalgo, plenamente consciente de que estaba solo y sin el apoyo del gobierno federal, concluye su discurso expresando que eran injustas toda una serie de acusaciones que le hacían:

No habrán sido ajenas a vuestros oídos las más duras invectivas contra el Gobierno por esta línea de conducta; sin la menor reflexión se le atribuyen por las clases acomodadas, afinidad con el zapatismo, etc., etc., pero la tranquilidad que inspira una recta intención, me hacen esperar mejores días para que aquilatada mi labor, se juzgue en definitiva si, contribuyendo a la conservación de

62 "Discurso pronunciado por el C. Antonio Hidalgo, gobernador constitucional del Estado", en el Periódico oficial del gobierno del estado de Tlaxcala, Tlaxcala, 5 de octubre de 1912 , p. 340.

63 Loc. cit. 
la paz, ha sido al fin un resguardo para los intereses mismos de las clases que hoy por hoy creen o fingen creerse lastimadas. ${ }^{64}$

\section{Otra vez el asalto de las haciendas}

En medio de un contexto social sumamente agitado, el panorama se complica con la nueva aparición de grupos rebeldes en distintos puntos de la entidad. Se trata de la presencia de huestes zapatistas, las cuales extienden sus actividades bélicas hacia Puebla y Tlaxcala. En suma, estas fuerzas rebeldes en línea de lucha frontal contra la oligarquía, consuman otra oleada de asaltos de varias haciendas, como lo cuenta a mediados del mes de octubre de 1912 un diario. Se trata de la hacienda de Santa Marta, propiedad de Ricardo Carvajal y que dista apenas unos tres kilómetros de la ciudad de Tlaxcala. Los asaltantes eran cerca de $30 \mathrm{za}-$ patistas, capitaneados por Victorio Meneses, y de quien se decía era el culpable de toda una serie de males causados a las haciendas del Valle de San Martín Texmelucan y las contiguas del estado de Tlaxcala. Por otra parte la finca se encontraba resguardada por los hijos del propietario. Los rebeldes zapatistas les exigen mil pesos que al parecer no tenían. Como había la amenaza de quitarles la vida, los hijos del hacendado maniobran en forma oportuna logrando quitarles la vida tanto al jefe como a varios de los asaltantes. ${ }^{65}$ Este desenlace inesperado provoca que el resto de los asaltantes huyeran de la hacienda. La misma nota periodística destaca que semejante ola de violencia y de bandidaje, era la resultante lógica de la actitud pasiva y de indiferencia del gobernador.

Pero el asalto a la hacienda de Santa Marta era sólo parte de una larga cadena. Se menciona que para entonces los rebeldes habían cometido sus tropelías en alrededor de una docena de haciendas, entre ellas la de Coaxamalucan, Tochac, Totolquexco, Notario, La Compañía, Santa Bárbara, Aculco, Rancho de Guadalupe, Rancho de la Concepción, Teometitla y Tepeyahualco, ${ }^{66}$ cuestión que había orillado a que "los dueños de esas fincas se hayan ausentado de ellas, temerosos de perder la vida". ${ }^{67}$ Esto, por supuesto, no era del agrado del gobierno federal. En uno de sus viajes a la capital de la república, Antonio Hidalgo tiene que informar a las máximas autoridades de la magnitud de los asaltos a las haciendas. ${ }^{68}$

\section{El "Yo acuso" de los peones acasillados}

Los movimientos de huelga impulsados tanto por el gobernador como por los dirigentes del PAT entre los peones acasillados, constituyen quizás uno de los ataques más violentos que hasta entonces se hubieran lanzado en contra de la oligarquía. Pero en forma sumamente sutil, los hacendados explotaron al máximo la idea de que tales movimientos escondían una conspiración en contra de Madero, que los peones estaban

64 Loc. cit.

65 "No hay hacienda en Tlaxcala que se libre de un asalto. La paz es sólo obra de los telegramas oficiales", en El Pais, 20 de octubre de 1912.

66 Además de la referencia anterior, consultar el Periódico oficial del gobierno del estado.

de Tlaicala, Tlaxcala, 16 de noviembre de 1912, p. 392.

67 Loc. cit.

68 "El señor Hidalgo en México", en El Imparcial, 19 de octubre de 1912. 
siendo soliviantados por las autoridades locales para levantarse en armas, saquear las fincas e incendiarlas, a más de asesinar a sus propietarios.

En cuanto al gobernador, cuando le faltaban unos tres meses para concluir su mandato, Hidalgo comienza a doblegarse. Deja de tener el valor suficiente para llevar hasta las últimas consecuencias su alianza con el campesinado. Incluso se olvida de sus planes de derogar o cuando menos revisar la fatídica ley de 1882 . Al parecer todo lo contrario ocurría entre sus correligionarios del PAT, quienes no tenían la menor intención de claudicar. Mas era evidente que el gobernador estaba siendo cercado por la presión no sólo de los hacendados sino también del gobierno federal. Porfirio del Castillo dice que a causa de esta postura del gobernador, "la huelga se liquidó en setenta y dos horas, sin garantías específicas para los trabajadores quienes regresaron a las fincas más sojuzgados que antes". ${ }^{69}$ Pero no obstante su derrota, los peones tuvieron la fuerza suficiente para echarle en cara al gobierno federal su falta de sensibilidad. Le hacen de su conocimiento las razones por las cuales se habian jugado el todo por el todo lanzándose a una huelga en extremo temeraria.

En un memorial dirigido al propio presidente de la república, conocido como el "Yo acuso", le hacen ver que de ninguna manera estaban dispuestos a seguir soportando las jornadas laborales de 15 horas diarias; que las tareas en el campo eran tan excesivas que tenían que ser ayudados por sus mujeres e hijos o bien completar su jornada en día y medio; que en muchas haciendas se les pagaba con fichas para obligarlos a comprar en la tienda de raya; que en las haciendas en las que se les pagaba con monedas, de todas formas estaban obligados a comprar en la tienda de raya; que cn su calidad de peones percibían salarios misérrimos de apenas 38 centavos diarios y algo de maíz; que los niños utilizados en las haciendas ganaban diariamente entre 6 y 12 centavos; que estos niños, por lo general, eran tratados en forma in humana, eran golpeados por los capataces; que tenían la obligación de trabajar aun estando enfermos; que entre la ración semanal de maíz, se les mezclaba maíz podrido; que por la menor falta o descuido, se les encerraba en la cárcel particular de la finca por todos conocida como la tlapixquera, sin descartar que se les recetaran los consabidos golpes. Pruebas de todo ello no les faltaban. Por ejemplo, señalan que en los momentos del auge huelguístico estaba encamado en el hospital de Huamantla un peón de la hacienda de Xalpatlahuaya castigado por el administrador a causa de que no había acarreado agua suficiente para la casa del trojero; que en algunas fincas, como la de Tepeyahualco, eran obligados a ir a misa y a los que faltaban se les aplicaba una multa de 10 centavos por cada miembro de la familia; que en haciendas como la de Cuamancingo, los dueños mantenían guardias personales a su servicio con los que mandaban catear las casas de los peones sospechosos para someterlos a sus caprichos; que bajo cualquier pretexto eran amenazados por el hacendado con ser consignados al servicio de las armas o ante las autoridades. Finalmente, concluyen que a juicio del propietario o bien del administrador y por el más leve motivo, eran despojados de sus pegujales que cultivaban en unión de sus familiares. ${ }^{70}$ Lo notable de esta propuesta es que coincide con otra expresada por los

70 Porfirio del Castillo, op. cit. pp. 101-103 y Ezequiel M. Gracia, op. cit., p. 32. 
peones de la hacienda de San Lorenzo Techalote. Esta última la dirigen al secretario de Gobernación. Los peones de esta hacienda, no obstante que ya se habían vuelto demasiado incrédulos, aún tenían ciertas esperanzas de que sus lamentos fueran atendidos por las autoridades federales. Todo ello a pesar de que como ya se ha advertido, era patente que al gobierno federal solo le interesaba mantener el orden social. De todas formas, la protesta de los peones acasillados no deja de ser un testimonio lacerante e indicativo de que algo andaba mal en las haciendas. A mediados de octubre de 1912 le manifiestan al secretario de Gobernación que:

Teniendo en cuenta que ante usted los seffores hacendados miembros de "I a Liga de Agricultores" han ocurrido repetidas veces llamándose víctimas de nuestros actos que pintan con los colores más negros, tenemos tambjén la pena de distraerle a usted para llevarle nuestras quejas las cuales daran a usted sefor Ministro, idea exacta de nuestra situación, y se convencerá por ellos que nuestros esfuerzos pacíficos y ordenados, no reclaman más que justicia. A todos nosotros que formamos la gran masa del peonaje del campo, somos perjudicados injustamente cuando se nos hace aparecer como peligrosos, siendo que somos nosotros las víctimas eternas de los más caprichosos de nuestros patrones. ${ }^{71}$

También como en el contenido del memorial enviado a Madero, los peones acasillados denuncian que la jornada laboral alcanzaba las 16 horas diarias; que a las tres de la mañana se les pasaba lista de asistencia rigurosa; que si algún peón no se presentaba a pasar lista, era multado con 5 o 10 centavos; que las jornadas de trabajo eran sumamente arduas alcanzando entre las 25 varas de ancho por 275 varas de largo en el magueyal. Sobre este particular hacen ver que tales tareas eran muy superiores a la fuerza humana. Que si por desgracia no terminaban tales tareas, no se les liquidaba el día; que se les pagaba con las tradicionales fichas valederas en las tiendas de raya de la finca. Como prueba de ello le envían al secretario de Gobernación una ficha de 6 centavos asegurándole que era similar a otras de distinto valor. Que se les pagaba cuando el patrón quería, generalmente los domingos a las nueve de la mañana, sin importarle si los peones tenían o no necesidades urgentes que cubrir; que si alguno de ellos se enfermaba y no podía ir a trabajar, simplemente no se le pagaba el día ni se le daba la ración acostumbrada de maíz. No obstante esto último, al fin de la semana se le apuntaba el abono de costumbre para engrandecer su deuda con la hacienda. ${ }^{72}$

Pero lo que sí les parecía en extremo paradojico a los peones de la hacienda de San Lorenzo Techalote, era que no entendían por qué se habían pasado tantos años trabajando y sus deudas en lugar de desaparecer, crecían y no podían ser liquidadas:

Habemos muchos que desde hace largos anoos trabajamos en la hacienda, y nunca sabemos efectivamente lo que debemos, siendo que sólo una vez al año, en Semana Santa se nos da el llamado "préstamo" de diez pesos, y alguna pequeña cosa que pedimos en el curso del año.

Sin embargo de esto, cuando se nos hacen nuestras cuentas cada fin de anua-

71 "Varios obreros de las haciendas de San Lorenzo Techalotepec, estado de Tlaxcala, con fecha 14 del actual, presentaron un ocurso a esta Secretaría que dice lo siguiente. Al C. secretario de Fomento", México, 26 de octubre de 1912, en el Archivo General de la Nación, Ramo Trabajo, caja 11, expediente 25.

72 Loc. cit. 
lidad, aparecemos en los libros verdaderamente vendidos. Jamás se nos dan libretas con nuestras cuentas, así de préstamos como de abonos, y por lo tanto ignoramos nuestros adeudos, quedando todo al arbitrio de los dependientes o del dueño. Si a alguno de nosotros se nos ocurre pedir nuestras cuentas, se nos vetan los libros diciêndonos que les liquidemos y que ya sabemos cuándo se hacen las cuentas. 73

Otra acusación de los peones de esta hacienda, asesorados por los dirigentes del PAT, era que no obstante su condición de mexicanos con pleno disfrute de sus derechos políticos, éstos les habían sido esquilmados. A causa de su condición de peones de las haciendas, carecían de garantías constitucionales y de derechos políticos:

\begin{abstract}
Ahí se verifican elecciones y nombran electores cuantas veces se ofrecen, pero nosotros jamás nos damos cuenta del porqué y cómo. Por eso nos extraña la conducta de nuestros patrones de la Liga de Agricultores, y aún se exponen a que como hoy, alcemos nuestra humilde voz desmintiéndolos, y dejando a usted el juicio sobre el particular. Llegando hasta nosotros ese ánimo que embarga a todos los ciudadanos de la República, queremos conquistar nuestra soberanía conculcada, sin más derechos que por ser sirvientes humildes, y al afiliarnos al Partido Liberal Antirreeleccionista, formado con elementos populares netamente, ha sido motivo para que en nosotros se aumenten las penalidades y nuestros amos recrudezcan sus malos tratamientos y atropellos. ${ }^{74}$
\end{abstract}

Finalmente, señalaban que no pocos de ellos se habian atrevido a abandonar las haciendas cansados de soportar tanta tiranía. Pero que los peones que lograban romper las ataduras con la hacienda y alcanzar su libertad, eran "despedidos con gran grosería y salimos no para hacer huelga como lo han dicho, sino para ir a buscar trabajo en los pueblos, como ya lo han hecho muchos". ${ }^{75}$ Sobra decir que tales denuncias no conmueven ni a Madero ni al secretario de Gobernación o al de Fomento.

\title{
La recuperación de la confianza entre los hacendados
}

Por supuesto que los hacendados se dan cuenta de que conforme pasaba el tiempo eran más apoyados por el gobierno federal. Si bien no habían tenido éxito en derrocar al gobernador, sí consiguieron doblegar a los peones. Una prueba de ello se encuentra en la respuesta de José Manuel y de Benigno Prieto, dueños de la hacienda de San Lorenzo Techalote. El último día de octubre le escriben al secretario de Gobernación expresándole que en el periódico La Nueva República, del 19 de octubre e impreso en la propia imprenta del gobierno de Tlaxcala, habían visto con bastante pena y no menos sorpresa, que eran calumniados por personas que se decían peones de su finca, pero cuyas firmas no veían estampadas en el periódico de referencia:

Sentimos mucho, señor Ministro, distraer por un momento la muy ocupada atención de usted, pero las circunstancias en que nos colocan nuestros detractores nos obligan a ello. Aseguran estos individuos que a las tres de la mañana levantamos a nuestros peones y los tenemos trabajando hasta las siete de la no- 
che. ¿Qué hombre por fuerte que se le suponga, puede trabajar dieciséis horas diarias, sin ser agotadas en muy pocos días sus fuerzas?

Tal aseveración, por inverosímil no debería merecer el honor de la contestación.

Otro de los cargos que se nos hacen es que damos a los peones tareas de 25 varas de ancho por 275 de largo en el magueyal, o sea seis mil ochocientas setenta y cinco varas cuadradas. Bien se conoce que la persona que dio estos números ignora por completo que clase de tareas son las que se dan a los peones y como las desempeñan. Se asegura igualmente que pagamos a los peones su raya cuando queremos y si alguno se enferma, no se le abona el tiempo de enfermedad y sin embargo se le apunta el abono de costumbre; y más abajo se dice que hay muchos peones que hace largos años trabajan en nuestra finca. ${ }^{76}$

Asumiendo una postura de víctimas, los señores Prieto agregan que "No comprendemos cómo siendo nosotros tan crueles con nuestros peones, hay muchos que desde hace largos años trabajan con nosotros sin haber elevado antes sus quejas". ${ }^{77}$ Expresiones que hacían sabiendo de antemano que los peones siempre se habían quejado y que las autoridades jamás les hicieron caso. Que los peones no podían abandonar la hacienda a causa de que carecian de capacidad de pago, que prácticamente ninguno de los de su clase podía cubrir sus adeudos.

Como se puede observar, la defensa que hacen los hacendados para sostener el statu quo, carece de elementos sólidos. No aportan pruebas contundentes que echaran abajo los puntos de vista de los peones. Con la excepción de las medidas de las tareas diarias en las que sí existe un error, los hacendados se limitan a repetir los argumentos expresados por los peones. Pero en contra de la postura de éstos y de otros muchos hacendados, existía el precedente de las acusaciones similares que los peones hacían no sólo en Tlaxcala sino en otras partes del país. De ninguna manera se trataba de acusaciones nuevas u originales. En lo único en que sí resultan tener la razón los hacendados, era en culpar de la insolencia de los peones a la labor de agitación ejercida por los dirigentes del Comité Central del Partido Antirreeleccionista de Tlaxcala. Para concluir, los hacendados aseguran que tenian la mejor disposición, al igual que todos los miembros de su gremio, para proporcionar a los trabajadores del campo toda clase de comodidades.

\section{La supresión de la huelga de los peones y la satanización del gobernador}

En los últimos meses de 1912, los hacendados y en general las clases dominantes de todo el país, arreciaron su campaña contra Madero. A pesar de que no les había afectado sus intereses, tratan de reemplazarlo por un personero mucho más confiable, por alguien que les garantizara el inmediato retorno a los viejos tiempos.

Los hacendados de Tlaxcala, confiados por el resultado de la huelga de los peones, buscan extinguir todo virus de descontento y de rebelión. Ellos y sus administradores hacen lo posible por contrarrestar la labor de agitación de los miembros del PAT. Casi al mismo tiempo, y en forma por demás brutal, el propio secretario de Gobierno de Tlaxcala, involu-

76 "Ciudadano ministro de Gobernación. De José Manuel Prieto y Benigno Prieto", México, 31 de octubre de 1912, en el Archivo General de la Nación, Ramo Trabajo, caja 11, expediente 25 .

77 Loc. cit. 
crado directamente en la labor de agitación campesina, les da la espalda a los peones. Porfirio del Castillo asegura que este funcionario, de nombre Néstor González, no hizo más que seguir "la política de su amigo, el ministro de Gobernación, quien estaba desautorizando nuestra conducta y a toda costa necesitaba poner fin al problema de la huelga". ${ }^{78}$ Ezequiel M. Gracia afirma que no sólo se trataba del ministro de Gobernación, quien se oponía a la huelga, sino también el de Fomento, ya que

por intrigas del secretario de Fomento, licenciado Rafael Hernández, se considera la primera huelga de los peones como una conspiración en contra del Presidente Madero, por lo que éste ordenó a la Secretaría de Gobernación que la desautorizara teniendo que regresar los peones a sus trabajos sin lograr ningún beneficio, y que se volvieran a tener reservas del Gobernador, porque afirmaba que estaba armando a sus correligionarios para enfrentarlos a la administración federal. ${ }^{79}$

No obstante toda la campaña adversa que se desencadena contra el gobernador, nadie puede negar que éste realizó

una programada obra de apoyo a los obreros ante los dueños de las fábricas de hilados y tejidos para lograr aumento de salarios, disminución de las horas de trabajo y trato humano; de defensa de los peones acasillados, que aún vivían la tragedia de la época de la colonia española, mediante la intervención de los correligionarios que, como Marcelo Ramírez, peón semanero oriundo de San Francisco Atezcatzinco, Arturo Serrano y los amigos de Zacatelco, además de tener gran arraigo en el campo, estuvieron resueltos a actuar en la peligrosa tarea libertaria: de aceptar con simpatía la primera huelga de campesinos acasillados y semaneros tlaxcaltecas. 80

En lo que serían los últimos días de 1912, los hacendados no pierden la oportunidad tanto de atacar al gobernador como de quitar de sus haciendas a la gente calificada de perniciosa. Poco tiempo le quedaba a Antonio Hidalgo en la gubernatura pues tenía que entregarla el 15 de enero de 1913. El curso de los acontecimientos le sería bastante desastroso. Los hacendados agrupados en la Liga de Agricultores arrecian su campaña de desprestigio sobre un gobernador que se iba quedando solo.

A Hidalgo le quedaba un esperanza: que su sucesor en la gubernatura fuera Pedro Corona. Y así lo indicaban los primeros resultados de las elecciones difundidos en el Periódico oficial del gobierno del Estado. Ahí se consigna que en cinco de los seis distritos electorales, Pedro Corona, postulado por el PAT, había obtenido 162 votos contra 69 del candidato de la Liga de Agricultores, Diego L. Kennedy. Otros candidatos a gobernador obtienen 21 votos en conjunto. Pero el triunfo del candidato del PAT es fuertemente cuestionado. ${ }^{81}$ En medio de un panorama político en extremo polarizado, los hacendados refuerzan su campaña de des-

78 Porfirio del Castillo, op. cit, p. 102-103. Néstor González, presionado por el secretario de Gobernación, llega a decir que los harapos, la mugre y la escualidez de los peones, de sus mujeres e hijos, era propio de gentes que no sabían bañarse, ni vestirse y sólo procuraban beber pulque.

79 Ezequiel M. Gracia, op. cit., p. 34.

80 Ibidem, p. 30-31.

81 Ver "Elección para gobernador en Tlaxcala", en el Periódico oficial del gobierno del estado. Tlaxcala, Tlaxcala, 19 de octubre de 1912, p. 358-360. 
prestigio tanto en contra de Pedro Corona como del gobernador. Inclusive la oligarquía local no vacila en utilizar toda clase de ardides. Un personaje que firma con el nombre de J. Santos Cos, acusa directamente a Antonio Hidalgo de que tuvo "ingerencia directa en las huelgas [...] ocurridas en casi todas las haciendas". 82 Pero también acusan a sus subalternos más inmediatos. El corresponsal en Tlaxcala de El País, quien se había distinguido por su odio acérrimo sobre el gobernador, asegura que "era cosa enteramente sabida que el secretario de la Prefectura Política es quien anda alborotando a los pueblos para que los peones se declaren en huelga y que el gobernador Hidalgo no persigue a los bandidos que constantemente atacan la hacienda de La Concepción de don Próspero Cahuantzi." 83

La andanada de ataques no para ahí. El corresponsal de marras, y tal como lo había hecho en enero del mismo año, asegura que estaba

en posesion de datos completos para demostrar que el gobernador Hidalgo ha sido el directo promovedor de las huelgas en las haciendas del Estado, causando con esto un grave dańo a los jornaleros que recibían anticipos de importancia desde tiempo inmemorial, el día de Todos Santos, y ahora los hacendados se resisten a darles tales préstamos, en virtud de los movimientos huelguísticos que permiten a los trabajadores abandonar las fincas sin pagar sus deudas tan solo por las incitaciones de las autoridades que debieran procurar que hubiera orden en el Estado, en vez de excitar los ánimos y promover dificultades. Nada extraño es que las autoridades que propagan las huelgas e incitan a los peones a que abandonen su trabajo, profesen la teoría de que el Palacio de Gobierno es para ocultar criminales y las fuerzas del Estado para resistir las ordenes de un juez competente. ${ }^{84}$

Esta versión, cuando menos por lo que tocaba a los peones, no era del todo cierta. Los peones difícilmente quedaban en libertad ante la más leve incitación de los dirigentes del PAT. Ante todo tenían que cubrir las deudas contraídas en las haciendas, como lo marcaba la ley de 1882 , so pena de ser acusados de cometer el delito de fraude. Como se ha visto, estos movimientos surgidos en las entrañas mismas de los peones acasillados y semaneros distaban mucho de los conflictos derivados del despojo de tierras o bien de la petición de reparto de la gran propiedad. Simplemente se buscaba que las condiciones laborales tanto de los peones acasillados como la de los semaneros fueran mejoradas. Hasta cierto punto, se trataba de las mismas demandas de los obreros textiles.

Con el paso de los días, Hidalgo ya no tuvo tiempo de defenderse de los ataques de sus detractores. En forma desesperada trata de hacer valer el triunfo del candidato del PAT para gobernador, ya que ello le significaba la posible continuidad de su línea política. Pero los hacendados apoltronados en la Liga de Agricultores no estaban dispuestos a ceder un ápice y refuerzan su cruzada en aras de la recuperación de la gubernatura. Con la consumación de este objetivo, ya no les sería problema echar abajo cualquier medida de tinte reformista que pretendiera afectar sus intereses. Los hacendados tienen éxito ya que consiguen que sus personeros en el congreso local anulen la elección para gobernador. Hidalgo se queda solo y como último recurso acude ante el gobierno federal planteando la desaparición de los poderes. El argumen-

82 "Las huelgas en Tlaxcala", en El Pais, 23 de octubre de 1912.

83 "No fue aprehendido el gobernador de Tlaxcala", en El Pals, 30 de octubre de 1912.

84. "No ha sido electo todavía el señor Corona", en El Pals, 31 de octubre de 1912. 
to consiste en que no existía quorum en el congreso local para que hiciera la declaratoria oficial de quién era el ganador de las elecciones, cuestión que se complica con el hecho de que el propio Hidalgo estaba a punto de concluir su mandato. A causa de ello solicita a la federación que se declarara la desaparición de los poderes en la entidad. Pero ia federación no le hace caso. Por su parte, el congreso local designa a Agustín Sánchez en calidad de depositario del poder ejecutivo. El 15 de enero de 1913 entra en funciones este nuevo gobernador, lo que significa el virtual retorno al poder de las viejas clases dominantes. ${ }^{85}$

A pesar del fracaso de la huelga de los peones acasillados y de los semaneros, no todo resultó negativo. Se demostró que no todo el personal político emergido de las filas maderistas era de tintes conservadores; que varios de ellos tenían plena conciencia de que no todo se limitaba a quitar a Díaz y poner a otro personaje en su lugar; que había la urgente necesidad de llevar a cabo una política de profundas transformaciones económicas y sociales; que no era posible seguir ignorando las voces y los lamentos de desesperación de las clases más desprotegidas en una entidad tapizada de hacendados. En la capital de la república, un mes más tarde, Victoriano Huerta consuma el golpe de estado en contra de Madero. Y como la historia lo demuestra, éste no pudo solicitar la ayuda de una clase como el campesinado por la cual no tuvo más que indiferencia y desconfianza.

Eso tiene vastas repercusiones en Tlaxcala, ya que se abre un periodo de tiempo en el que los gobernadores, además de que son militares, se alían fuertemente con los hacendados. Durante un año y medio la oligarquía agraria nada tuvo que temer. Pero la semilla de la liberación de los peones acasillados sembrada por el gobernador Antonio Hidalgo y los dirigentes del PAT germina contra viento y marea. Al poco tiempo deja de ser una esperanza y una utopía. Con el arribo del constitucionalismo al poder, este ansiado anhelo se consuma. En septiembre de 1914 Pablo González decreta la abolición de las deudas de los trabajadores, no sólo de las haciendas, sino también de las fábricas en Puebla y Tlaxcala. ${ }^{86}$ Con ello se daba fin a la diabólica y secular cadena que ataba a los peones acasillados a las haciendas. Les abre las puertas de su libertad.

Pero como se sabe, la guerra civil aún estaba lejos de terminar y es difícil determinar si las nuevas autoridades se preocuparon por vigilar el estricto cumplimiento de esta disposición revolucionaria. Por lo demás, subsistía el peligro de que los peones volvieran a quedar convertidos en esclavos por deudas a causa de la virtual vigencia de la ley de 1882, que reglamentaba el trabajo en las haciendas. En todo caso, la disposición del caudillo constitucionalista se convertía en un mal presagio para el futuro de la oligarquía.

85 "Alcance. Al periódico oficial del estado de Tlaxcala correspondiente al 25 de enero de 1913. Dictámenes emitidos por la Segunda Comisión de Puntos constitucionales y Segunda de Gobernación de la Cámara de Senadores, en el conflicto entre los Poderes Legislativo y Ejecutivo del Estado, y oposición del ex Gobernador C. Antonio Hidalgo, para desalojar el Palacio de Gobierno", documento intercalado en el Periódico oficial del gobiemo del estado. Tlatcala, Tlaxcala, 8 de febrero de 1913.

86 Porfirio del Castillo, op. cit., p. 103. 


\section{ANEXO I}

J. MARIANO GRAJALES, GOBERNADOR CONSTITUCIONAL DEL ESTADO LIBRE Y SOBERANO DE TLAXCALA, A SUS HABITANTES, SABED:

No. 123

Art. 1. Los sirvientes domésticos o de campo, jornaleros, empresarios de obras a destajo o precio alzado, están estrictamente obligados a cumplir los contratos que celebraron al comprometer su trabajo, y por el tiempo que hubieren estipulado, no pudiendo éste pasar de un año.

Art. 2. Los menores de catorce años podrán contratarse, según la costumbre recibida, con aprobación y autorización de sus padres o de las personas que legalmente hagan las veces de éstos, no pudiendo comprometerse por más cantidad que la que racionalmente puedan devengar en un año.

Art. 3. Concluido el término del convenio, será cada año en la Semana Mayor o el que hubiere costumbre en cada Distrito, podrá el operario, en este tiempo, separarse de la finca, devolviendo la cantidad que adeude a su principal, avisándole en tiempo oportuno su separación o voluntad para continuar si a ello quisiere comprometerse.

Art. 4. Todos los años, en la misma Semana Mayor o época acostumbrada en cada Distrito, liquidará el encargado de la finca a los operarios dependientes su cuenta anual; ya sea para que éstos se separen o continúen en ella. Si alguno se quejare de que en el tiempo designado no se le hubiere liquidado su cuenta, el Juez, con conocimiento de causa, hará que se practique la liquidación, imponiendo al contraventor una multa de diez pesos aplicables a los fondos municipales.

Art. 5. A los tlachiqueros que sirven al partido se les liquidarán sus cuentas y pagarán sus alcances semanariamente. El que de ellos abandonare la tanda de magueyes que se le tiene confiada, está obligado a resarcir los perjuicios que cause tal abandono y será perseguido con arreglo al Código Penal. En todo lo demás queda sujeta esta clase de dependientes a lo que dispone la presente ley, acerca de los operarios.

Art. 6. El operario o dependiente que se desacomodare de una finca, recabará de su principal una constancia que expresará si no queda adeudado en aquélla o si debe algo que esté en obligación de devolver.

Art. 7. La persona que sin esta constancia recibiere a un peón, dependiente o tlachiquero adeudado o comprometido por determinado tiempo en otra fínca, estará obligado a devolverlo y no tendrá derecho a cobrar la cantidad que le hubiere suplido hasta después de haber pagado su compromiso anterior.

Art. 8. Todo sirviente que habiendo recibido anticipo en cuenta de su trabajo se negare a prestarlo o devolver la cantidad recibida, comete el delito de fraude y será castigado con las penas que para la estafa señala la ley penal vigente; pero si hubiere causa justa calificada por autoridad competente para no cumplir su compromiso, devolverá sólo la cantidad que adeude.

Art. 9. La persona que ocupe a los operarios comprendidos en el artículo anterior y después se negare a pagarles el jornal o retribución estipulada, comete también el delito de fraude, que será castigado conla pena señalada en el Código vigente.

Art. 10. Los cómplices en el delito de fraude de que habla el artículo 
anterior incurren en las mismas penas señaladas por el Código penal vigente.

Art. 11. La persona que sedujere a jornalero o sirviente de otra parte y que por su causa no cumpliere su compromiso, será responsable de los perjuicios a que dé lugar y en caso de insolvencia sufrirá la pena que para estos casos marca el referido Código.

Art. 12. El operario, sirviente o empresario de obras que justificare recibir maltratamiento de su principal o superior u otro género de castigo que pugne con las leyes, podrá separarse de la finca devolviendo lo que adeude, sin perjuicio de que el infractor sufra la pena que con arreglo a éstas le corresponda.

Art. 13. Ningún labrador tiene derecho para obligar a sus peones al trabajo de las llamadas faenas los días destinados al descanso, bajo la multa, si lo hicieren, hasta de veinte pesos, que podrán exigir para los fondos municipales las autoridades respectivas.

Art. 14. Los principales no podrán cargar a la cuenta de los hijos las deudas que los padres contrajeron para devengar con su propio trabajo, bajo la pena de pagar la cantidad que cargaren aplicable a los fondos de instrucción primaria.

Art. 15. Las autoridades cuidarán el exacto cumplimiento de esta ley y de que los operarios reciban buen tratamiento por los dueños de las fincas y sus principales dependientes, de que disfruten de justa libertad, de que sea a precios corrientes lo que se les ministre para el sustento y vestuario, asimismo de que los operarios cumplan estrictamente con las obligaciones que hayan contraído para con sus principales.

Art. 16. Los dueños o encargados de haciendas y ranchos, por pequeños que éstos sean, tendrán la obligación de fijar un ejemplar de la presente ley en lugar visible, bajo la multa de cinco a diez pesos que se impondrá al infractor por la autoridad respectiva, aplicándola a los fondos de instrucción primaria.

Por lo tanto, mando se imprima, publique, circule y cumpla. Palacio de Gobierno del Estado. Tlaxcala, diciembre 7 de 1882. J. Mariano Grajales. (Tomado de El Estado de Tlaxcala, órgano oficial del gobierno, Tlaxcala, 9 de diciembre de 1882, p. 1-2) 